\title{
Hæðarveiki og tengdir sjúkdómar
}

Tómas Guðbjartsson ${ }^{1,2}$

Engilbert Sigurðsson ${ }^{2,3}$

\section{Magnús Gottfreðsson $2,4,5$ \\ Ólafur Már Björnsson ${ }^{6}$}

\section{Gunnar Guð̃mundsson ${ }^{2,7}$}

Höfundar eru allir læknar.

${ }^{1}$ Hjarta- og lungnaskurðdeild, ${ }^{2}$ ææknadeild Háskóla Íslands, ${ }^{3}$ geðsviði Landspítala, ${ }^{4}$ vísindadeild, ${ }^{5}$ smitsjúkdómadeild Landspítala, ${ }^{6}$ Sjónlag augnlæknastöð, 7 lungnadeild Landspítala.

Fyrirspurnum svarar Tómas Guðbjartsson, tomasgudbjartsson@hotmail.com

\section{Inngangur}

Sífellt fleiri Íslendingar sækja í göngu- og fjallahjólaferðir, skíðaiðkun og fjallaklifur erlendis par sem fjöll eru hærri en 2500 metra yfir sjávarmáli, en í peirri hæð getur hæðarveiki gert vart við sig. Á mynd 1 sjást hæstu svæði jarðar, par á meðal eru Himalajafjöll, Andesfjöll í S-Ameríku, Klettafjöll í N-Ameríku og Alparnir í Evrópu. Nokkrar stórborgir eru í mikilli hæð og pegar lent er á flugvöllum par gefst enginn tími fyrir hæðaraðlögun. Dæmi um petta er borgin La Paz í Bólivíu, í 3640 metra hæð yfir sjávarmáli (mynd 2). Líkaminn bregst við súrefnisskorti með pví að setja í gang aðlögunarferli. Pessi viðbrögð líkamans duga pó ekki alltaf til eða geta orðið of kröftug og hvort tveggja getur valdið hæðarveiki (high altitude illness). Langalgengasta birtingarform hæðarveiki er háfjallaveiki (acute mountain sickness, AMS) en lífshættulegir sjúkdómar eins og hæðarheilabjúgur (acute mountain cerebral edema, HACE) og hæðarlungnabjúgur (high altitude

\section{Á G R I P}

Pegar komið er yfir 2500 m hæð yfir sjávarmáli geta einkenni hæðarveiki gert vart við sig innan nokkurra daga. Áhættan ræðst einkum af hæð og hraða hækkunar og einkennin eru fjölbreytt. Háfjallaveiki er langalgengust en lífshættulegur hæðarheilabjúgur og hæðarlungnabjúgur geta einnig komið fram. Orsök hæðarveiki er súrefnisskortur og ófullnægjandi hæðaraðlögun, en meingerð sjúkdómanna sem hæðarveikin getur valdið ræðst af viðbrögðum líkamans við súrefnisskorti. Algengustu einkenni háfjallaveiki eru höfuðverkur, preyta, slappleiki, ógleđi og lystarleysi, en svefntruflanir og meltingarópægindi eru sömuleiðis algengar kvartanir. Algengustu einkenni hæðarlungnabjúgs eru mæði og próttleysi en helstu einkenni hæðarheilabjúgs eru jafnvægistruflanir auk pess sem ruglástand getur próast og meðvitundarskerðing átt sér stað. Hér er fjallað̛ um öll pessi prjú birtingarform hæðarveiki, fyrirbyggjandi ráðstafanir og meðferð en einnig nýja pekkingu á meingerð.

pulmonary edema, HAPE) geta einnig próast, einkum pegar komið er yfir 3000 metra hæð., ${ }^{1,2}$

Pessi grein er skrifuð með breiðan hóp lækna í huga en algengt er að leitað sé til lækna eftir ráðleggingum fyrir undirbúning og tilhögun háfjallaferða og ferða til staða sem liggja hátt yfir sjávarmáli. ${ }^{3}$ Greinin er töluvert breytt frá yfirlitsgrein um sama efni sem birtist í Læknablaðinu fyrir rúmum áratug ${ }^{4}$ og mun vonandi nýtast læknum, öðru heilbrigðisstarfsfólki, nemum í heilbrigðisgreinum og öðrum sem vilja fræðast um hæðarveiki á íslensku. Textinn byggist á helstu heimildum sem fundust á PubMED, MEDLINE og í heimildaskrám nýlegra yfirlitsgreina. ${ }^{5-9}$ Fyrst er fjallað um eðlilega hæðaraðlögun og lífeðlisfræði hennar en síðan greint frá birtingarmyndum og meinlífeðlisfræði peirra sjúkdóma sem geta gert vart við sig í mikilli hæð. Loks er útskýrt hvernig fyrirbyggja má hæðarveiki og meðhöndla.

Í grein í Læknablaðinu ${ }^{4}$ var heitið háfjallalungnabjúgur notað fyrir high altitude pulmonary edema og háfjallaheilabjúgur yfir high altitude cerebral edema. Viðtekin heiti nú eru hæðarlungnabjúgur og hæðarheilabjúgur. Háfjallaveiki er áfram notuð sem pýðing á sjúkdómsheitinu acute mountain sickness og hæðarveiki á high altitude illness.

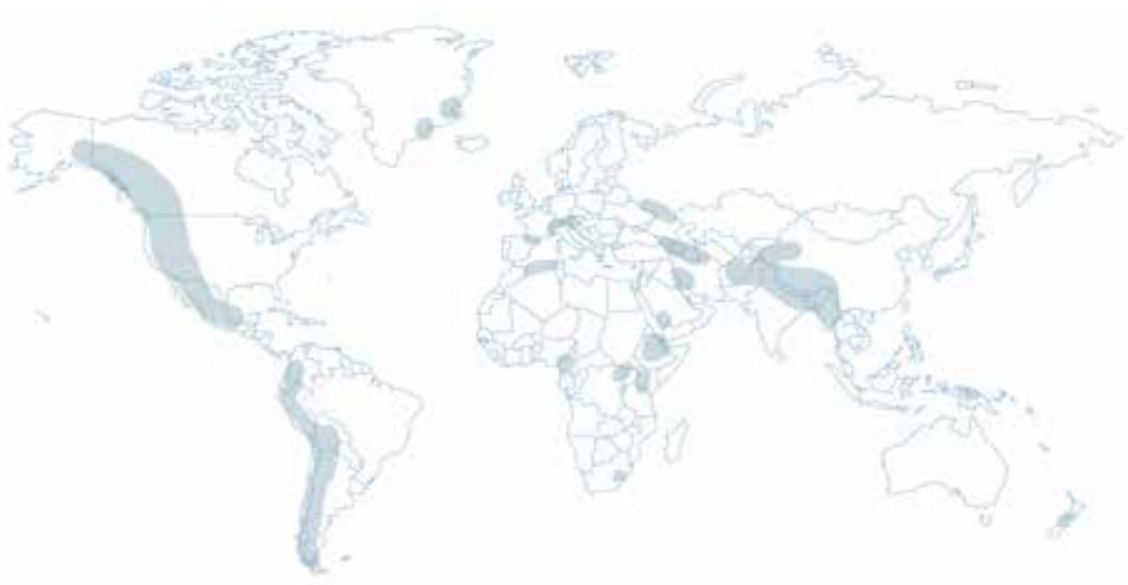

Mynd 1. Helstu háfjallasvæði heims. Mynd: Guðbjörg Tómasdóttir. 


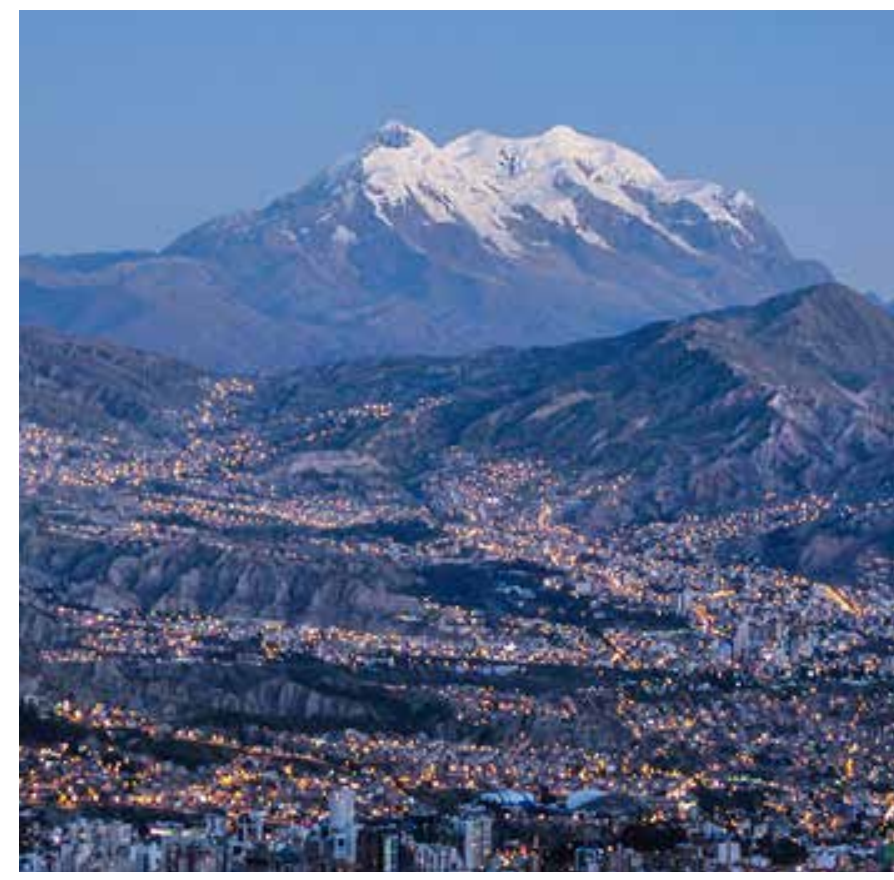

Mynd 2. La Paz er höfuðborg Bólivíu og jafnframt hæsta höfuðborg í heimi. Dar búa hátt i 800 púsund manns í $3640 \mathrm{~m}$ hæð yfir sjávarmáli en ferðamenn finna par gjarnan fyrir hæðarveiki. Í bakgrunni sést í fjallið Illiminani sem er 6438 m hátt og 18. hæsta fjall Suður-Ameríku. Mynd: Wikipedia: wikipedia.org/wiki/La_Paz

Ekki verður sérstaklega fjallað um langvinna háfjallaveiki eða Monge-sjúkdóm í pessu yfirliti. Hún greinist í peim sem búa í meira en 2500 m hæð, en talið er að rúmlega 140 milljónir manna búi við slíkar aðstæður (mynd 1). ${ }^{10}$ Sjúkdómurinn leiðir til aukins fjölda rauðkorna í blóði og lungnaháprýstings sem getur leitt til hægri hjartabilunar. ${ }^{11}$

\section{Lífeðlisfræði og hæðaraðlögun}

Við sjávarmál er hlutfall súrefnis í innöndunarlofti 21\% og helst hlutfallið lengst af óbreytt pegar hærra er komið, til dæmis á tindi Kilimanjaro (5895 m) og Everest (8848 m). Á hinn bóginn lækk-

Tafla I. Einkenni og teikn hæðarveiki.

\begin{tabular}{|c|c|c|}
\hline & Einkenni & Teikn \\
\hline \multicolumn{3}{|l|}{ Bráđ háfjallaveiki } \\
\hline væg & $\begin{array}{l}\text { Höfuðverkur, lystarleysi, } \\
\text { ógleði, svefntruflanir }\end{array}$ & Engin sértæk \\
\hline meðal & $\begin{array}{l}\text { Höfuðverkur (svarar } \\
\text { verkjalyfjum), lystarleysi, } \\
\text { ógleði, svefntruflanir, } \\
\text { sundl }\end{array}$ & Engin sértæk \\
\hline alvarleg & $\begin{array}{l}\text { Höfuðverkur (svarar illa } \\
\text { verkjalyfjum), } \\
\text { mikil ógleði, uppköst } \\
\text { og mikil preyta }\end{array}$ & Engin sértæk \\
\hline Hæðarheilabjúgur & $\begin{array}{l}\text { Höfuðverkur (svarar illa } \\
\text { verkjalyfjum), uppköst }\end{array}$ & $\begin{array}{l}\text { Slingur (ataxia), breytt } \\
\text { meðvitund (rugl), skert } \\
\text { viðbrögð, hálfdvali, dá }\end{array}$ \\
\hline $\begin{array}{l}\text { Hæðarlungna- } \\
\text { bjúgur }\end{array}$ & $\begin{array}{l}\text { Skert hreyfigeta, purr } \\
\text { hósti, mæði í hvíld, blóð } \\
\text { í hráka, andnauð }\end{array}$ & $\begin{array}{c}\text { Hraður hjartsláttur í hvíld } \\
\text { (>100 slög á mínútu), } \\
\text { hraðöndun (>25 á mínútu), } \\
\text { brak við lungnahlustun, } \\
\text { blámi }\end{array}$ \\
\hline
\end{tabular}

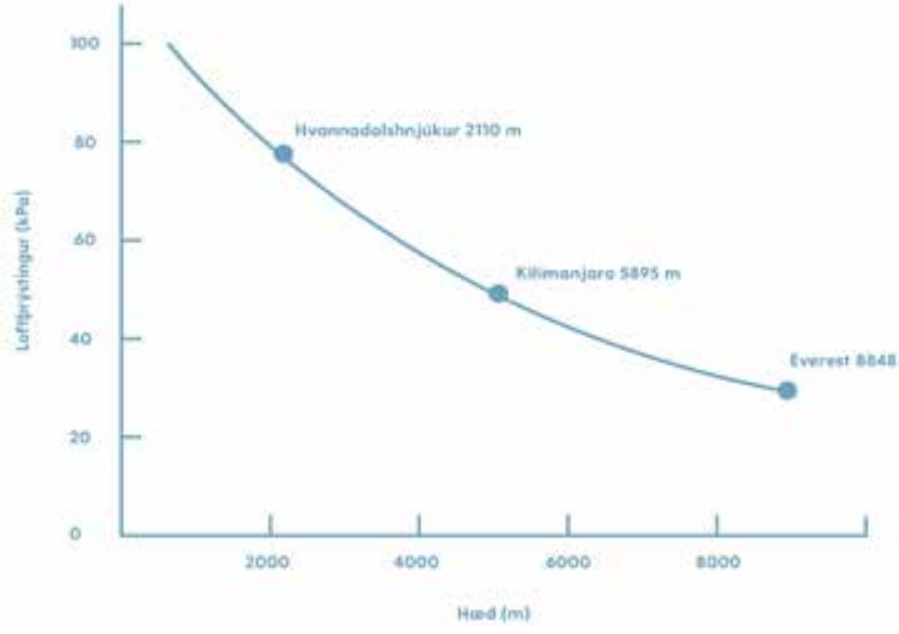

Mynd 3. Samband loftprýstings og hæðar yfir sjávarmáli. Mynd: Guðbjörg Tómasdóttir.

ar loftprýstingur í veldisfalli með aukinni hæð og í stað $760 \mathrm{~mm}$ kvikasilfurs (ígildi 1013 mbara, eða 101,3 kPa) við sjávarmál er hann aðeins helmingur pess á tindi Kilimanjaro og priðjungur á hæsta tindi jarðar, Everest. Par sem hlutprýstingur lofttegundar er afleiða af heildarprýstingi lækkar prýstingur innandaðs súrefnis sem nemur falli á loftprýstingi. Pannig er magn súrefnis í ákveðnu rúmmáli andrúmslofts á toppi Everest aðeins um priðjungur pess sem pað er við sjávarmál (mynd 3). Pegar komið er yfir 2500 m hæð er hætta á að súrefnisskortur fari að gera vart við sig. Til að nýta sem best pað súrefni sem er í boði setur líkaminn af stað hæðaraðlögun (acclimatization). ${ }^{12}$ Petta er flókið lífeðlisfræðilegt ferli og getur tekið vikur og mánuði að ná fullri verkun. ${ }^{12}$ Pannig lifir einstaklingur ekki lengi á toppi Everest án undangenginnar hæðaraðlögunar, ${ }^{13}$ en eftir 6-8 vikur í mikilli hæð geta sérpjálfaðir fjallgöngumenn klifið hæstu tinda jarðar án viðbótarsúrefnis. ${ }^{14}$

Flest líffæri aðlagast hæð, en viðbrögð öndunarkerfis, hjarta og blóðs vega pyngst. Við lækkun á súrefnisprýstingi í blóði örvast viðtakar í æðum til heila sem auka öndunartíðni og öndunin dýpkar, en hvort tveggja eykur loftskipti í lungnablöðrum. ${ }^{5} \mathrm{Um}$ leið lækkar hlutprýstingur koltvísýrings í blóði og sýrustig blóðs hækkar (respiratory alkalosis). Oföndunar verður oftast vart með dofa í fingrum og í kringum munn. ${ }^{15}$ Algengt er að mæði komi fram við minni áreynslu en áður, en öndunarrýmd skerðist vegna minni styrks innöndunarvöðva. Á móti kemur að mótstaða í öndunarvegum minnkar við lægri loftprýsting en auk pess veldur hærri blóðprýstingur í lungnablóðrás pví að blóð prýstist lengra út í lungnavef sem nýtist pannig betur til loftskipta. ${ }^{16}$ Hjartað eykur afköst sín með pví að hraða á sér og auka útstreymisbrot, en hvort tveggja styttir flutningstíma súrefnis til vefja. ${ }^{5,12,17}$ Nýru bregðast við hækkun sýrustigs í blóði af völdum oföndunar og auka útskilnað á bíkarbónati, en pað tekur nýrun nokkra daga að leiðrétta sýrustig blóðs. Jafnframt eykst pvagútskilnaður og getur vökvaskortur gert vart við sig ef pess er ekki gætt að drekka vel. 5,9 Nýru auka einnig framleiðslu sína á rauðkornavaka (erythropoietin) sem hvetur nýmyndun á rauðum blóðkornum í merg og nær hún hámarki eftir tvær til prjár vikur í hæð yfir $2500 \mathrm{~m}$. Magn blóðrauða eykst og par með getan til að flytja súrefni, en seigja blóðsins eykst einnig. Verði vökvaskortur minnkar blóðvatn (plasma) og seigja blóðsins vex enn frekar. Petta getur skert háræðablóðflæði út í fingur og tær og aukið hættu á kali. ${ }^{9,17}$ Mikil- 
Tafla II. Lake Louise skor fyrir háfjallaveiki. ${ }^{22}$

Höfuðverkur
0 - Enginn
1 - Vægur
2 - Meðal
3 - Svo slæmur að polandi verður óvirkur
Meltingarópægindi
0 - Góð matarlyst
1 - Léleg matarlyst eða ógleði
2 - Meðalslæm ógleði eða uppköst
3 - Slæm ógleði og uppköst sem gera polanda óvirkan

\section{Preyta og/eða slappleiki}

0 - Hvorki preyta né slappleiki

1 - Væg preyta/slappleiki

2 - Meðal slæm preyta/slappleiki

3 - Mikil preyta/slappleiki

\section{Svimi/jafnvægistruflanir}

0 - Hvorki svimi né jafnvægistruflanir

1 - Vægur svimi/jafnvægistruflanir

2 - Meðalslæmur svimi/jafnvægistruflanir

3 - Slæmur svimi/jafnvægistruflanir sem gera polanda óvirkan

Háfjallaveiki - virkniskor

Ef pú fannst fyrir einhverjum einkennum háfjallaveiki, hver voru áhrifin á virkni pína?

\section{$0-$ Engin}

1 - Einkenni til staðar en pau höfðu ekki áhrif á virkni eða ferðaáætlun

2 - Einkenni urðu til pess að ég gat ekki haldið uppgöngu áfram óstuddur eða purfti að halda niður

3 - Flytja varð mig brátt í lægri hæð

vægur hluti hæðaraðlögunar er að minna súrefni í blóði veldur pví að rauð blóðkorn eiga auðveldara með að losa súrefni í vefjum. ${ }^{17}$ Auk pess myndast „hypoxia-inducible factor-1a“ í súrefnissnauðum vefjum sem örvar nýmyndun æða. ${ }^{18}$ Við pað eykst blóðflæði

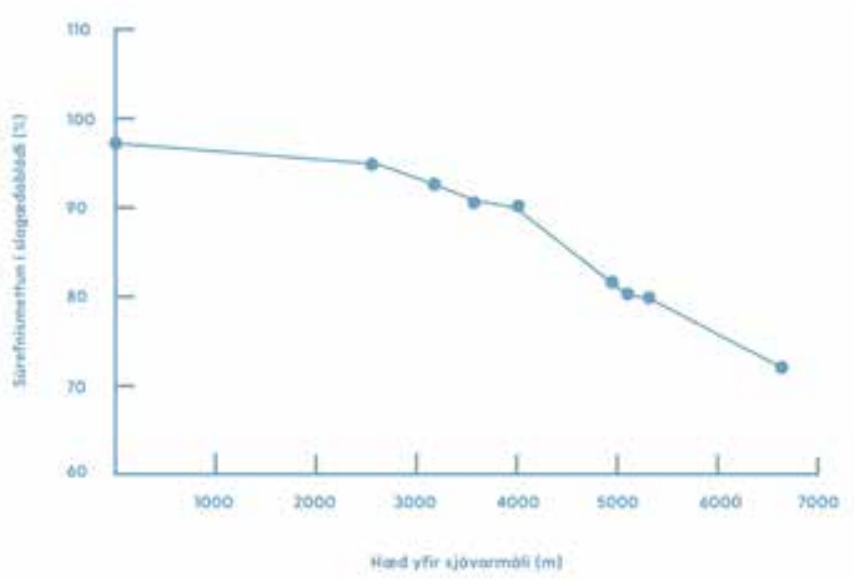

Mynd 4. Súrefnismettun í slagæðablóði fjallgöngumanna á Everest minnkar með aukinni hæð. Myndin er byggð á gögnum frá Dr. Nick Mason.

Mynd: Guðbjörg Tómasdóttir.
Tafla III. Áhættuflokkun hæðarveiki. ${ }^{7}$

\begin{tabular}{|c|c|}
\hline Áhætta & Lýsing \\
\hline \multirow[b]{2}{*}{ Lítil } & $\begin{array}{l}\text { Einstaklingur með enga fyrri sögu og hækkar sig í minna en } \\
2800 \mathrm{~m}\end{array}$ \\
\hline & $\begin{array}{l}\text { Einstaklingur sem tekur tvo daga í að komast í } 2500-3000 \text { m og } \\
\text { hækkar sig í svefnstað minna en } 500 \text { m á dag og tekur aukadag } \\
\text { til aðlögunar fyrir hverja } 1000 \text { m hækkun }\end{array}$ \\
\hline \multirow{3}{*}{ Meðal } & $\begin{array}{l}\text { Einstaklingur með fyrri sögu sem hækkar sig í 2500-2800 m á } \\
\text { einum degi }\end{array}$ \\
\hline & $\begin{array}{l}\text { Einstaklingur með enga sögu um hæðarveiki og hækkar sig í } \\
\text { meira en } 2800 \text { m á einum degi }\end{array}$ \\
\hline & $\begin{array}{l}\text { Allir sem hækka sig meira en } 500 \text { m á dag (hækkun í svefnstað) } \\
\text { í hæð yfir } 3000 \text { m en með auka degi fyrir aðlögun fyrir hverja } \\
1000 \text { m hækkun }\end{array}$ \\
\hline \multirow{5}{*}{ Mikil } & $\begin{array}{l}\text { Einstaklingur með fyrri sögu sem hækkar sig í meira en } 2800 \text { m } \\
\text { á einum degi }\end{array}$ \\
\hline & Allir með fyrri sögu um hæðarheilabjúg \\
\hline & Allir sem fara í meira en 3500 m hæð á einum degi \\
\hline & $\begin{array}{l}\text { Allir sem hækka sig meira en } 500 \text { m á dag (hækkun í svefnstað) í } \\
\text { hæð yfir } 3000 \text { m en með enga aukadaga fyrir aðlögun }\end{array}$ \\
\hline & $\begin{array}{l}\text { Mjög hröð uppganga, til dæmis á Kilimanjaro á innan } \\
\text { við } 7 \text { dögum }\end{array}$ \\
\hline
\end{tabular}

Með hæð er átt við pá hæð sem sofið er í. Gengið er út frá pví að hækkun byrij i 1200 m hæð eđa lægra. Ofangreint á við um pá sem hafa ekki fengið hæðaraðlögun.

og framboð súrefnis til vefja. Loks breytast efnaskipti í hvatberum til að tryggja sem besta nýtingu á súrefni í vefjum. ${ }^{19,20}$ Um er að ræða flókið ferli par sem breyting verður á ýmsum efnaferlum í hvatberum en einnig má sjá breytingar á byggingu peirra í rafsmásjá (mitochondral remodelling).

Á mynd 4 sést hvernig súrefnismettun í slagæðablóði minnkar með aukinni hæð, en upp að 5000 m hæð nær hæðaraðlögun að halda súrefnismettun í slagæðablóði yfir $80 \%{ }^{21}$ Eftir pað fellur súrefnismettun mun hraðar, áhrifin á líkamann verða meiri og hættan á hæðarveiki eykst. Til pess að pola slíka hæð parf margra vikna hæðaraðlögun, en fjallgöngumenn sem leggja til lokaatlögu við Everest og aðra tinda yfir 8000 metrum yfir sjávarmáli eru oft með blóðrauða í kringum 190 g/L. ${ }^{14}$

\section{Háfjallaveiki}

Bráð háfjallaveiki er samsafn einkenna par sem höfuðverkur er lykileinkenni en önnur ósértækari einkenni eru einnig oft til staðar (tafla I). ${ }^{5,9}$ Samkvæmt skilmerkjum sem kennd eru við Lake Louise og voru síðast uppfærð 2018 er um að ræða höfuðverk hjá einstaklingi sem ekki er hæðaraðlagaður og er nýkominn í meira en 2500 metra hæð yfir sjávarmáli (tafla II). ${ }^{22}$ Að auki er til staðar eitt eða fleiri af eftirtöldum einkennum: ópægindi frá meltingarvegi (lystarleysi, ógleði eða uppköst), sundl, prekleysi og preyta..22 Svefnleysi er hins vegar ekki lengur meðal skilyrða fyrir greiningu háfjallaveiki í pessari nýjustu útgáfu Lake Louise skilmerkjanna, enda hefur verið sýnt fram á að allt að 40\% sjúklinga með háfjallaveiki finna ekki fyrir svefntruflunum. ${ }^{22}$ Í töflu I eru auk einkenna sýnd helstu teikn sem finnast við skoðun á sjúklingum með háfjallaveiki. Að jafnaði koma einkenni fram 6-10 klukkustundum eftir komu í mikla hæð en geta hafist allt að einni 


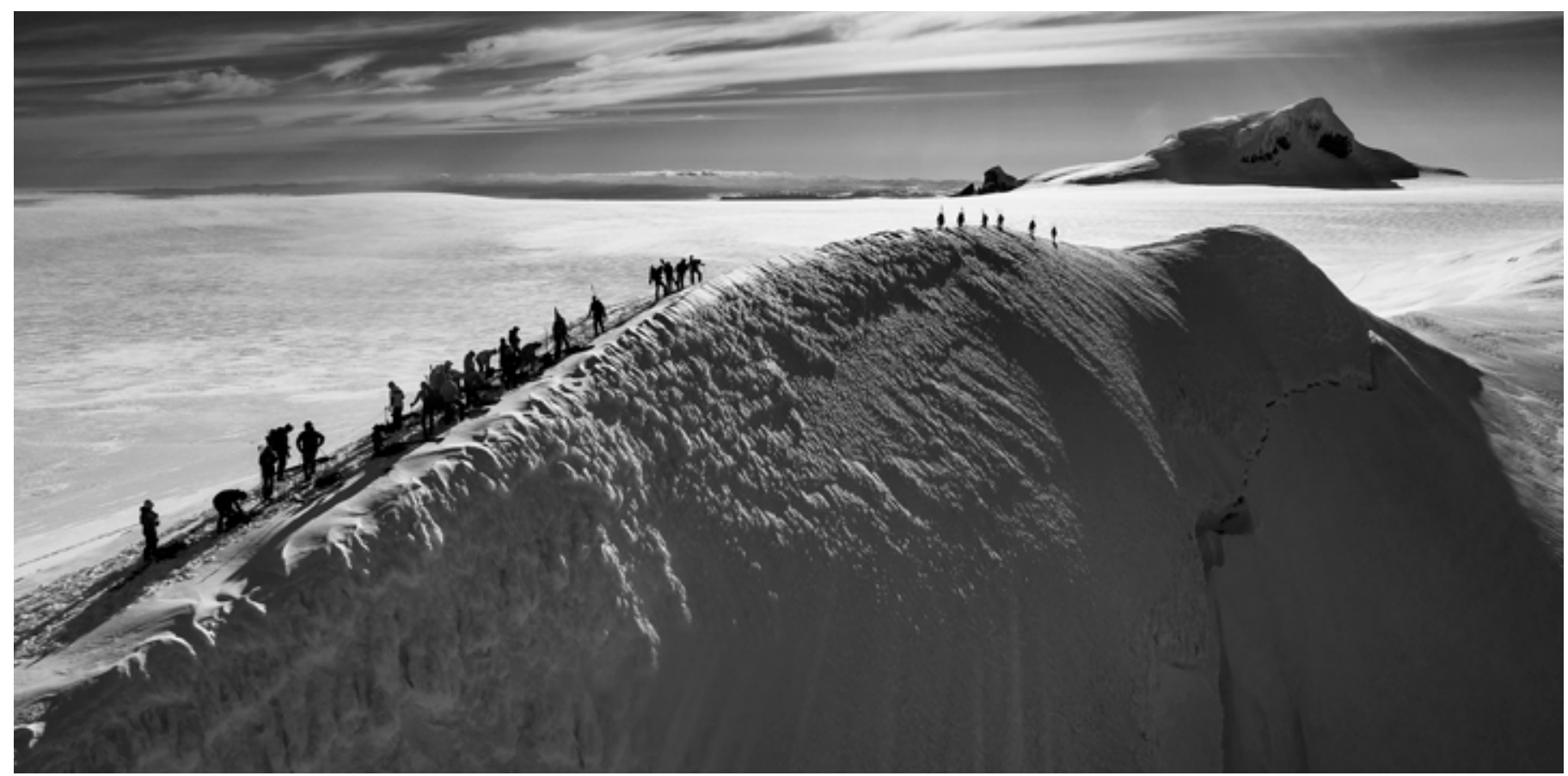

Mynd 5. Hópur fjallaskíðafólks á Sveinsgnípu (1925 m) i Öræfajökli, en hún er kennd við Svein Pálsson lækni og náttúrufræðing sem talið er að hafi stigið par fyrstur árið 1794. Í baksýn er Hvannadalshnjúkur, hæsta fjall á Íslandi, en par sem hann nær aðeins $2110 \mathrm{~m}$ hæð, og ekki $2500 \mathrm{~m}$, ætti frískt fólk ekki að finna fyrir hæðarveiki par né á öðrum íslenskum fjöllum. Mynd: Ólafur Már Björnsson.

klukkustund eftir komu eða einum til tveimur dögum síðar. ${ }^{5,9,15,17}$ Án frekari hækkunar ganga einkenni oftast til baka á einum til premur dögum.

Háfjallaveiki er algengt vandamál. Rannsóknir tengdar ferðamönnum í Klettafjöllum N-Ameríku hafa sýnt að 22\% ferðamanna sem náðu 2500-2900 metra hæð fundu fyrir einkennum og var tíðnin $42 \%$ pegar komið var yfir $3000 \mathrm{~m}$ hæð. ${ }^{23}$ Svipuðum niðurstöðum hefur verið lýst hjá göngufólki í Ölpunum og Nepal, eða 10-40\% peirra sem náðu $3000 \mathrm{~m}$ og 40-60\% hjá peim sem komust upp í 4000-5000 m. .24,25 Háfjallaveiki verður ekki vart undir 2500 metra hæð ${ }^{5}$ og pví gætir hennar ekki hjá heilbrigðu fólki á íslenskum fjöllum (mynd 5). Sjúklingum með hjarta- og æðasjúkdóma er pó hættara við að fá einkenni hæðarveiki í lægri hæð en öðrum.

\section{Hæðarlungnabjúgur}

Í 5500 metra hæð hefur nýgengi hæðarlungnabjúgs mælst 2-15\% og ræðst mest af hæðaraðlögun, pað er hraða hækkunar. ${ }^{26}$ Einstaklingar með hjartagalla eins og op á milli gátta geta pó veikst í minni hæð. ${ }^{27}$ Hæðarlungnabjúgur er pað form hæðarveiki sem talið er að dragi flesta til dauða. ${ }^{28}$ Hann kemur helst fram á fyrstu tveimur til fjórum dögunum eftir að komið er í 2500 til 3500 metra hæð. Fyrstu einkenni eru oft purr hósti, áreynslumæði og próttleysi við klifur eða pegar gengið er upp halla. Með aukinni vökvasöfnun í lungum sem veldur fallandi súrefnismettun sést oft vaxandi mæði við göngu á jafnsléttu, jafnvel andnauð. Einnig getur hráki orðið bleikur, froðukenndur eða blóðlitaður. Við hlustun á lungum má pá oftast heyra brakhljóð við lungnahlustun auk pess sem hiti getur verið til staðar. ${ }^{12}$ Mikilvægt er að hafa í huga að einkenni hæðarveiki, eins og ógleði og höfuðverkur, koma aðeins fram í um helmingi tilfella í aðdraganda hæðarlungnabjúgs og hjálpa pví lítið við aðgreiningu lungnabjúgs og loftvegasýkinga. ${ }^{29}$

\section{Hæðarheilabjúgur}

Hæðarheilabjúgur er lífshættulegt form hæðarveiki sem tengist breyttu vökvajafnvægi í smærri æðum heila pegar komið er yfir 2500 til 3000 metra hæð. ${ }^{17,30}$ Fyrst verður vart óstöðugleika við gang en við lengra genginn heilabjúg sést slingur (ataxia) og jafnvægisleysi sem síðan getur próast hratt í sljóleika og skerta áttun á stað og stund..$^{30}$ Í alvarlegustu tilfellum getur ruglástand próast og meðvitundarskerðing átt sér stað eða algert meðvitundarleysi. Líkt og með hæðarlungnabjúg er ekki vitað hvers vegna sumum er hættara við hæðarheilabjúg en öðrum. Meðal áhættupátta er fyrri saga um hæðarveiki, ófullnægjandi aðlögun og mikil líkamleg áreynsla. ${ }^{28,31}$ Hæðarheilabjúgur hefur heldur lægra nýgengi en hæðarlungnabjúgur og er áætlað að um 0,5-1\% einstaklinga fái slík einkenni pegar komið er í 4000-5000 metra hæð. ${ }^{17}$ Oftast hafa einkenni bráðrar hæðarveiki, eins og höfuðverkur og ógleði eða jafnvel einkenni hæðarlungnabjúgs, verið til staðar áður en einkenni hæðarheilabjúgs koma fram, en einnig er pekkt að hæðarheilabjúgurinn geti próast einn og sér án slíkra undanfara. Einkenni eru pó yfirleitt meiri hafi lungna- og heilabjúgur próast samhliða. ${ }^{30}$

\section{Meingerð hæðarveiki}

Meingerð hæðarveiki er flókið fyrirbæri sem rekja má til viðbragða líkamans við súrefnisskorti. Meingerð hæðarlungnabjúgs er aðeins frábrugðin meingerð háfjallaveiki og hæðarheilabjúgs sem oft er litið á sem svæsið form háfjallaveiki (mynd 6).

\section{Háfjallaveiki og hæðarheilabjúgur}

Enn er margt á huldu um hvað pað er sem ræsir sjúkdómsferlið en svo virðist sem peir sem pjást af háfjallaveiki séu með lægri súrefnismettun í blóði en hinir sem eru einkennalausir. ${ }^{9}$ Er talið að ýmsir pættir geti par komið við sögu, eins og skert öndunarstýr- 


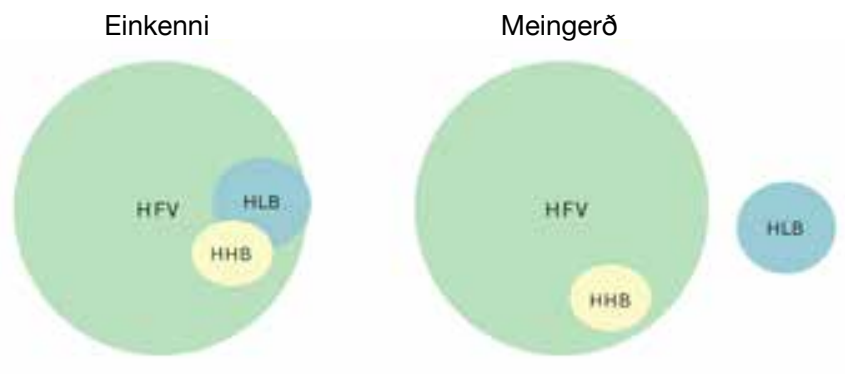

Mynd 6. Einkenni hæðarveiki skarast líkt og meingerð sömu sjúkdóma nema hvað meingerð hæðarlungnabjúgs er aðeins frábrugðin peirri fyrir háfjallaveiki og hæðarheilabjúg. Myndin er fengin úr fyrirlestri Mike Grocott og birt lítillega breytt með leyfi hans. HFV: háfjallaveiki, HLB: hæðarlungnabjúgur, HHB: hæðarheilabjúgur. Grafík: Guðbjörg Tómasdóttir.

ing (ventilatory drive) við lágum súrefnisprýstingi, skert loftskipti i lungnablöðrum vegna bjúgs í millifrumuvef, óeðlileg vökvasöfnun í líkamanum og aukin efnaskipti í vefjum. ${ }^{5,28,31}$ Súrefnisskortur kallar fram oföndun sem lækkar koltvísýring í blóði, en lækkun hans veldur víkkun á æðum til heila. Petta eykur blóðflæði til heilans, en í alvarlegum tilfellum af háfjallaveiki og hæðarheilabjúg er talið að háræðaleki geti aukið á bjúgmyndun í heilanum. ${ }^{5}$ Ýmsir pættir koma par við sögu sem hjá sjúklingum með hæðarheilabjúg valda bólgu í æðaveggnum og röskun á sérhæfðum boðefnum eins og vascular endothelial growth factor (VEGF). Bjúgurinn getur valdið svæsnum höfuðverk en pá er innankúpuprýstingur oft hækkaður og merki um heilabjúg hafa sést hjá sjúklingum sem náðist að rannsaka með segulómun ${ }^{31}$ Petta getur einnig valdið ógleði, uppköstum og prekleysi. Heilabjúgur er pó ekki til staðar í vægari tilfellum af háfjallaveiki og pá er talið að ýmis hormón og boðefni valdi höfuðverknum og meðfylgjandi einkennum, ekki ósvipað og sést í mígreni. ${ }^{28,32}$

\section{Hæðarlungnabjúgur}

Hjá peim sem fá hæðarlungnabjúg er talið að súrefnisskortur valdi staðbundnum lungnaháprýstingi sem getur hjá næmum einstaklingum valdið auknu blóðflæði til annarra svæða lungans, háræðaleka og lungnabjúg. ${ }^{27,33}$ Ekki er vitað hvað kemur af stað pessum staðbundna lungnaháprýstingi en bólga í æðaveggnum, aukin virkni sympatíska taugakerfisins og truflanir á frásogi salta og vökva í lungnablöðrum virðast koma við sögu. Lungnabjúgurinn skýrist ekki af skertri hjartastarfsemi og vinstri slegilsprýstingur er eðlilegur. Á síðustu árum hefur athygli rannsakenda beinst í auknum mæli að hlutverki æðapels og framleiðslu boðefnanna níturoxíðs (NO) og endópelíns-1. ${ }^{34}$ Bæði gegna mikilvægu hlutverki í stjórnun blóðprýstings, par á meðal í lungum, en NO er mjög kröftugt æðavíkkandi efni og endópelín er æðaherpandi. ${ }^{7,27}$ Rannsóknir hafa sýnt að sjúklingar með hæðarlungnabjúg hafa lægri NO-gildi í útöndunarlofti en heilbrigðir og endópelín finnst í hærri styrk í blóði peirra. ${ }^{20,35,36}$

Enn er ekki ljóst hvernig staðbundinn lungnaháprýstingur veldur lungnabjúg en lungnablöðrur sjúklinga með hæðarlungnabjúg virðast hafa aukið vökvagegndræpi og bláæðar í peim dragast óeðlilega mikið saman við súrefnisskort, sem skerðir blóðflæði frá lungnablöðrunum. Einnig virðist bólga í lungnablöðrunum koma við sögu og pær eiga erfiðara með að losa sig við vökva sem safnast upp í peim. ${ }^{17,27,28}$

\section{Áhættupættir hæðarveiki}

Sterkasti áhættupáttur hæðarveiki er hröð hækkun í mikilli hæð. Nánari áhættuflokkun með tilliti til hækkunar og fleiri pátta er sýnd í töflu III. Peir sem búa á láglendi eru í aukinni hættu að fá hæðarveiki samanborið við pá sem búa að staðaldri yfir 900 $\mathrm{m}$ hæð yfir sjávarmáli. ${ }^{1,5,17}$ Fyrri saga um hæðarveiki er einnig pekktur áhættupáttur, sérstaklega ef um var að ræða hæðarlungnabjúg, en allt að $60 \%$ peirra sem hafa slíka sögu veikjast að nýju með svipuðum einkennum, fari peir aftur í sömu hæð. ${ }^{2,533}$ Sterkasti áhættupáttur hæðarveiki er hraði hæðaraukningar og sér í lagi í hvaða hæð yfir sjávarmáli er sofið. Nýjustu rannsóknir benda ekki til pess að munur sé á tíðni hæðarveiki eftir kynjum. ${ }^{1,5,17,28}$ Aldur skiptir hins vegar máli og eru einstaklingar milli fimmtugs og sjötugs í minni hættu að fá háfjallaveiki en peir sem yngri eru, en pegar komið er yfir 70 ára aldur eykst hættan á ný. ${ }^{5,28}$ Ofáreynsla og sýkingar, sérstaklega í öndunarfærum, eru pekktir áhættupættir fyrir hæðarlungnabjúg, einnig saga um offitu og lungna- og hjartasjúkdóma.5,12,28,37 Umdeilt er hvort vökvatap sé sjálfstæður áhættupáttur hæðarveiki ${ }^{5,28,38}$ og sama á við reykingar pótt sumar nýlegri rannsóknir virðist benda til ívið lægri tíðni hjá reykingafólki. ${ }^{39}$ Pó er alls ekki mælt með reykingum sem hluta af hæðaraðlögun.

Mjög góð líkamleg pjálfun og mikið áreynslupol eru ekki verndandi fyrir hæðarveiki og margt bendir til að keppnismenn í polgreinum íprótta, eins og í maraponhlaupi og sundi, séu ekki síður útsettir en aðrir.,13,20,28,40 Par að auki hafa rannsóknir á nokkrum af fremstu háfjallagörpum sögunnar, meðal annars Reinhold Messner, sýnt að peir eru ekki með betra áreynslupol en afreksmenn í ýmsum öðrum polgreinum íprótta. ${ }^{41}$

Á síðasta áratug hafa rannsóknir í sívaxandi mæli beinst að hlutverki erfða í meingerð hæðarveiki en flest bendir til pess að erfðir geti að hluta skýrt mismunandi næmi fyrir sjúkdómnum. ${ }^{20,34,42}$ Rannsóknir á pjóðflokkum frá Tíbet sem búið hafa öldum saman í mikilli hæð hafa sýnt að peir eru mun síður næmir fyrir hæðarveiki en Kínverjar sem á síðustu áratugum hafa flutt til Tíbet af láglendi. ${ }^{1,5,28,43}$ Erfðabreytileika í nokkrum genum hefur verið lýst en sterkust eru tengslin við breytileika í geni sem skráir fyrir angiotensin-converting enzyme (ACE-gen), en angiotensín eru mikilvæg boðefni við stjórnun æðasamdráttar almennt í líkamanum. ${ }^{34,44}$ Pannig hefur verið sýnt fram á afbrigði af ACE-geni sem tengist minni hættu á hæðarveiki hjá arfhreinum einstaklingum, og pá sérstaklega minni hættu á hæðarlungnabjúg. ${ }^{1,43-45}$ Í rannsókn á tæplega hundrað fjallgöngumönnum tókst pó ekki að sýna fram á jafn ótvíræð tengsl hæðarveiki og arfbreytileika í ACE-geni. ${ }^{46}$ Í annarri japanskri rannsókn var hins vegar sýnt fram á mismunandi tjáningu gena sem stýra framleiðslu NO (nitric oxide synthase, NOS) og sú tjáning var tengd mismunandi næmi einstaklinga fyrir hæðarveiki. ${ }^{47}$

\section{Fyrirbyggjandi meðferð}

Ýmsum aðferðum má beita til að fyrirbyggja hæðarveiki, bæði almennum en einnig sértækari lyfjameðferð. Hér er fjallað um helstu ráðleggingar; annars vegar fyrirbyggjandi meðferð gegn háfjallaveiki og hæðarheilabjúg og hins vegar hæðarlungnabjúg. 


\section{Hæðarveiki og hæðarheilabjúgur}

Almennar rádleggingar

Til að forðast hæðarveiki gildir enn sú gullna regla í fjallamennsku að gefa sér nægan tíma til hæðaraðlögunar.7 Pví miður gleymist pessi gamla regla oft í annríki nútímans. Varast skal að halda beint frá sjávarmáli upp í meira en 2700-3000 metra hæð yfir sjávarmáli. Best er að dvelja yfir nótt í meðalhæð (til dæmis 2500-2800 m) áður en lengra er haldið upp á við. Eftir pað er mælt með pví að hækkun sé ekki meiri en 500-600 m á dag milli svefnstaða og að taka hvíldardag fyrir hverja 1000-1200 m hækkun. ${ }^{7}$ Oft skiptir hæð yfir sjávarmáli á næturstað meira máli en sú hæð sem gengið er upp í yfir daginn. Pannig ná flestir hæðaraðlögun með pví að lækka sig í hæð í næturstað eftir dagsgöngu. ${ }^{7}$ Gott er að ganga rólega og reyna ekki of mikið á sig. Petta á sérstaklega við um pá sem áður hafa fengið hæðarveiki. ${ }^{28}$

Lyf

Helstu lyf sem hægt er að nota til að fyrirbyggja eða meðhöndla háfjallaveiki og hæðarheilabjúg eru sýnd á töflu IV. Parasetamól og ósérhæfðir COX-hamlar (til dæmis íbúprófen) hafa góð áhrif á háfjallahöfuðverk og er enginn afgerandi munur á virkni peirra samkvæmt nýlegum rannsóknum. ${ }^{48,49}$ Peim sem ætla að ferðast frá sjávarmáli upp í meira en $3000 \mathrm{~m}$ hæð til næturgistingar án hæðaraðlögunar er oft ráðlagt að íhuga að taka lyf sem draga úr líkum á hæðarveiki. Langoftast er gripið til asetasólamíðs sem er karbónik-anhýdrasa hemill sem dregur úr endurupptöku bíkarbónats og natríums í nýrum. Рað veldur pví losun á bíkarbónati í pvagi og par með blóðsýringu (metabolic acidosis). Við pað eykst öndunartíðni til að leiðrétta sýrustig í blóði sem aftur eykur súrefnisupptöku í lungum. ${ }^{50}$ Samkvæmt Cochrane-safngreiningu frá árinu 2017 virtist lyfið draga verulega úr líkum á háfjallaveiki með áhættuhlutfall 0,47 (95\%-ÖB: 0,39-0,56). ${ }^{51}$ Alls var um að ræða 16 rannsóknir með samtals 2301 páttakendum. Í tiltölulega fáum rannsóknanna hefur aukaverkunum verið lýst, eða í 5 peirra sem tóku til 789 pátttakenda og var par meðal annars lýst umtalsverðri aukningu á náladofa (áhættuhlutfall 5,53, 95\%-ÖB: 2,8110,88). Ennfremur bragðast kolsýrðir drykkir eins og gosdrykkir og bjór ekki vel á asetasólamíð-meðferð. Ekki er pó talið að allir sem fara í mikla hæð purfi að taka asetasólamíð til að fyrirbyggja hæðarveiki. Peir sem hafa áður fengið meira en aðkenningu af háfjallaveiki ættu pó að íhuga fyrirbyggjandi lyfjameðferð með lyfinu. Sömuleiðis ættu peir sem fara mjög hratt upp án hæfilegrar hæðaraðlögunar að taka lyfið til að draga úr líkum á hæðarveiki., ${ }^{7,52}$ Algengast er að nota asetasólamíð, 125 mg eða 250 mg, tvisvar á dag. Nýleg rannsókn sýndi að lágur skammtur, 62,5 mg tvisvar á dag, hafði ekki síðri verkun en 125 mg af asetasólamíði tvisvar á dag. ${ }^{53}$ Byrjað er að taka lyfið sólarhring fyrir hæðaraukningu og hætt pegar aftur er komið niður fyrir 2500 m, eða ef staldrað er við í sömu hæð í meira en 4-5 sólarhringa ${ }^{7}$ Ekki má gefa asetasólamíð peim sem hafa ofnæmi fyrir súlfalyfjum vegna mögulegs krossofnæmis.7 Til að ganga skugga um að lyfið polist vel er mælt með að prófa lyfið við sjávarmál um tveimur vikum fyrir áætlaða notkun.

Sykursterinn dexametasón er talinn draga úr háræðaleka í heila og par með minnka líkur á heilabjúg. Nota má hann í samráði við lækni sem fyrirbyggjandi meðferð ef asetasólamíð polist ekki eða frábendingar eru fyrir notkun pess. ${ }^{7,54,55}$ Cochrane-safngreining sem birtist árið 2017, og tók til fjögurra rannsókna með samtals 176 pátttakendum, sýndi að lyfið dró ekki marktækt úr áhættu á háfjallaveiki en pó vantaði lítið upp á að tölfræðilegri marktækni væri náð (áhættuhlutfall 0,60, 95\%-ÖB: 0,36-1,00). ${ }^{51}$ Ekki er ráðlegt að taka sykurstera í meira en 10 daga samfleytt vegna hættu á aukaverkunum og mikilvægt er að hafa í huga að einkenni hæðarveiki geta komið fram aftur pegar lyfjagjöf er hætt. ${ }^{56}$ Ýmis önnur lyf hafa verið rannsökuð með tilliti til pess hvort pau fyrirbyggi hæðarveiki en í peim hópi eru helst magnesíum sítrat og Ginkgo biloba. Flestar rannsóknir sem gerðar hafa verið, meðal annars safngreiningar, styðja ekki virkni peirra. ${ }^{57}$

\section{Hæðarlungnabjúgur}

Að jafnaði gilda sömu fyrirbyggjandi leiðbeiningar og fyrir bráða háfjallaveiki.7 Pó er sérstaklega mælt með pví að forðast of mikla áreynslu, sérstaklega hjá peim sem eru með öndunarfærasýkingu. Ekki er mælt með kalsíumhemlinum nífedipíni til að fyrirbyggja lungnabjúg nema fyrir pá sem áður hafa fengið hæðarlungnabjúg. ${ }^{58}$ Peir einstaklingar ættu að hækka sig varlega og taka langvirkandi nífedipín, 30-60 mg daglega. Nífedipín veldur víkkun á lungnaslagæðum og dregur pannig úr æðaherpingnum sem súrefnisskorturinn veldur, sem aftur minnkar líkur á lungnabjúg. Fosfódíesterasa-hemlarnir tadalafíl og síldenafíl virðast hafa svipuð áhrif og nífedipín. ${ }^{59}$ Með pví að hamla fosfódíesterasa verður meira framboð af níturoxíði (NO) í lungnaslagæðum sem veldur útvíkkun peirra án pess að hafa áhrif á kerfisblóðprýsting. Langvirkur beta-viðtakaörvi, salmeteról, hefur verið gefinn í innúðaformi í hærri skömmtum en notaðir eru við meðferð lungnasjúkdóma eins og astma og lungnateppu. Рað er talið geta flýtt fyrir að vökvi sé tekinn upp úr lungnablöðrum með pví að hafa áhrif á flutning á natríum og kalíum yfir frumuhimnur. ${ }^{60}$ Cochrane-safngreining frá 2017 staðfesti virkni salmeteróls við að fyrirbyggja lungnaeinkenni háfjallaveiki (áhættuhlutfall 0,37, 95\%-ÖB: 0,230,61), en rannsóknin náði til tveggja rannsókna með 132 pátttakendum. ${ }^{51}$

\section{Meðferð}

Almennar rádleggingar

Mikilvægast er að fara strax niður í minni hæð og skal pað alltaf gert ef aðstæður leyfa. ${ }^{7}$ Ef einkenni eru væg má íhuga að halda kyrru fyrir. Oft dugar lækkun um 500-1000 m til að draga verulega úr einkennum. Eftir hvíld og frekari hæðaraðlögun má reyna uppgöngu á ný ef einkenni voru væg. Ekki er mælt með pví að peir sem hafa fengið heila- og/eða lungnabjúg reyni frekari uppgöngu. ${ }^{61}$ Pá er áhersla lögð á að drekka vel og svala porstanum jafnóðum, og forðast pannig vökvatap sem jafnframt dregur úr einkennum háfjallaveiki. Ofvökvun er óæskileg, enda getur hún valdið lækkun á natríum í blóði sem getur valdið einkennum sem líkjast háfjallaveiki. ${ }^{62,63}$

\section{Lyf og önnur meðferð við háfjallaveiki}

Lyf má nota ein sér ef einkenni eru væg eða ef aðstæður leyfa ekki lækkun í minni hæð, til dæmis vegna veðurs eða náttmyrkurs. Nota má verkjalyf eins og parasetamól í fullum skömmtum eða 
Tafla IV. Lyf til að fyrirbyggja og meðhöndla hæðarveiki. Byggt á heimild númer 7.

\begin{tabular}{llll}
\hline Lyf & Ábending & Inntaka & Skammtur \\
\hline Asetasólamíð & Fyrirbyggja HFV, HHB & Um munn & 125 mg tvisvar á dag \\
& Meðferð HFV, HHB & Um munn & 250 mg tvisvar á dag \\
\hline Dexametasón & Fyrirbyggja HFV, HHB & Um munn & 2 mg á 6 klukkutíma fresti eða 4 mg á 12 tíma fresti \\
& Meðferð HFV, HHB & Um munn, í æð eða í vöðva & HFV 4 mg á 6 klukkutíma fresti. HHB: 8 mg fyrst, svo 4 mg á 6 tíma fresti \\
\hline Íbúprófen & Fyrirbyggja HFV & Um munn & 600 mg prisvar á dag \\
\hline Nífedipín & Fyrirbyggja HLB & Um munn & 30 mg langvirkt tvisvar á dag eða 20 mg langvirkt prisvar á dag \\
& Meðferð HLB & Um munn & 30 mg langvirkt tvisvar á dag eða 20 mg langvirkt prisvar á dag \\
\hline Tadalafíl & Fyrirbyggja HLB & Um munn & 10 mg tvisvar á dag \\
\hline Síldenafíl & Fyrirbyggja HLB & Um munn & 50 mg prisvar á dag \\
\hline Salmeteról & Fyrirbyggja HLB & Innöndun & 125 míkrógr tvisvar á dag \\
\hline
\end{tabular}

HFV: háfjallaveiki, HHB: hæðarheilabjúgur, HLB: hæðarlungnabjúgur

íbúprófen við vægum einkennum, sérstaklega höfuðverk. Tafla IV sýnir hvaða lyfjum má beita hjá sjúklingum með alvarlegri einkenni háfjallaveiki. Eins og fram kom í Cochrane-greiningu frá 2018 vantar vandaðar rannsóknir á gagnsemi pessar lyfja við háfjallaveiki. Pær takmörkuðu rannsóknir sem pó hafa verið gerðar benda engu að síður til virkni lyfjanna. ${ }^{64}$ Asetasólamíð er best að gefa sem fyrst eftir að einkenni koma fram en til vara dexametasón sem er kröftugra lyf og má gefa í töfluformi, í vöðva eða í æð. Asetasólamíð er áhrifaríkast fyrir pá sem eru með væga háfjallaveiki. Ef einkenni lagast eftir að lyfjagjöf hefst er ekki endilega pörf á að fara í lægri hæð. Dexametasón er frekar notað ef um er að ræða háfjallaveiki á miðlungs- eða háu stigi. ${ }^{7}$ Aldrei er mælt með pví að halda í meiri hæð fyrr en einkenni eru gengin yfir. Súrefnisgjöf í nef dregur fljótt úr einkennum en er sjaldan i í boði, enda súrefnishylki pung í burði. Sérstakir háprýstipokar (Gamow-pokar) sem sjúklingurinn fer í og prýstingur hækkaður með fót- eða handdrifnum dælum, geta komið sér vel og samsvara hæðarlækkun um allt að 3000 m.7 Pokana getur pó verið erfitt að nota ef einstaklingur er með innilokunarkennd eða uppköst.

\section{Meðferð hæðarlungnabjúgs}

Mikilvægast er að halda í lægri hæð en háprýstipoki getur komið að góðum notum pegar flutningi niður verður ekki komið við. Súrefnisgjöf, til dæmis 1-2 lítrar/mín sem gefnir eru með súrefnisbeisli, er áhrifarík en er oft ekki í boði í mikilli hæð. Hægt er að gefa nífedipín-töflur, 10-20 mg fyrst, en síðan 30-60 mg af langvirku formi á 12 klukkutíma fresti. ${ }^{65}$ Önnur lyf sem lækka lungnaslagæðaprýsting, eins og fosfódíesterasa-hamlarnir tadalafíl eða síldenafíl, geta einnig komið að notum. ${ }^{66}$ Rannsóknir hafa sýnt að peir lækka lungnaprýsting í mikilli hæð. ${ }^{66}$ Pessi lyf voru gefin í tæplega helmingi tilvika á heilsugæslustöð í 4240 metra hæð í Nepal með góðum árangri og stundum með öðrum lyfjum. ${ }^{67}$ Mælt er gegn notkun pvagræsilyfja og morfíns við hæðarlungnabjúg enda geta pvagræsilyfin aukið á vökvaskort í líkamanum. ${ }^{58}$

\section{Meðferð hæðarheilabjúgs}

Mikilvægast er að koma sjúklingnum sem fyrst neðar í fjallið og eins neðarlega og aðstæður leyfa og á alltaf við nema ytri aðstæður hamli. Við slíkar aðstæður getur háprýstipoki verið viðeigandi ${ }^{7}$ en einnig súrefnisgjöf ef hún er í boði. Stundum er gripið til dexa- metasóns í töfluformi eða í æð eða vöðva ef aðstæður leyfa, og er pá gefinn $8 \mathrm{mg}$ upphafsskammtur og síðan $4 \mathrm{mg}$ töflur á 6 klukkutíma fresti.?

\section{Sérstök heilsuvandamál tengd hæðarveiki}

\section{Svefntruflanir}

Svefntruflanir eru algengar pegar komið er í mikla hæð yfir sjávarmáli. ${ }^{68}$ pær geta stafað af ýmiss konar umhverfishljóðum sem trufla svefn en einnig af framandi svefnaðstæðum eins og pegar sofið er í tjaldi eða péttsettnum skála. Súrefnisskortur er talinn aðalástæðan fyrir pessum svefntruflunum, sem meðal annars lýsir sér með bilkvæmri öndun (Cheyne Stokes öndun). ${ }^{69}$ Hún er algeng í mikilli hæð en lagast oft með asetasólamíði. ${ }^{70}$ Einstaklingar sem finna fyrir miklum svefntruflunum prátt fyrir asetasólamíð geta tekið svefnlyf eins og zolpidem sem ekki bælir öndun eins og flest önnur svefnlyf.7

\section{Háfjallahósti}

Algengt er að fá hósta pegar komið er í mikla hæð. Ástæður pessa eru margar en öndun verður hraðari og loftið oft purrara, sem purrkar öndunarvegina og eykur líkur á hósta. ${ }^{71}$ Einnig er oft mikið ryk í lofti á háfjöllum og bakteríu- og veirusýkingar berast auðveldlega á milli einstaklinga í pröngum rýmum eins og tjaldi. Pá getur hósti framkallast vegna berkjuauðertni, til dæmis hjá peim sem eru með astma. ${ }^{72}$ Auk pess er talið að hóstaviðbrögð verði næmari í mikilli hæð en rétt er að hafa í huga að vægur hæðarlungnabjúgur getur komið fram sem hósti. ${ }^{73}$ Hægt er að meðhöndla loftvegasýkingar með sýklalyfjum og astma með berkjuvíkkandi lyfjum og pannig minnka hósta en oft er hvíld og lækkun í minni hæð áhrifaríkari til að draga úr vandamálinu. Kódeinlyf eru oft reynd til að stilla hósta og má nota $30 \mathrm{mg}$ af kódeini prisvar til fjórum sinnum á dag. Ef hóstinn er aðallega að næturlagi má gefa kódein að kvöldi. Hafa ber í huga öndunarbælandi áhrif og tilhneigingu til hægðatregðu tengda kódeinlyfjum. ${ }^{71}$

\section{Meltingartruflanir}

Breytingar á mataræði og meltingu fylgja gjarnan ferðalögum til annarra menningarheima. Á háfjöllum er hreinlætisaðstaða og aðgengi að fersku vatni oft af skornum skammti og erfitt að halda 
mat ferskum. Hægt er að drepa bakteríur með suðu sé hægt að koma pví við. Pá er unnt að grípa til síunar, en iðraveirur geta borist í gegnum pær og sú aðferð er pví ekki fyllilega örugg. Klórtöflur og joðtöflur hafa einnig verið notaðar til að drepa sýkla en pá parf vatnið að vera sæmilega tært og helst síað áður. Pessu til viðbótar má hreinsa vatn án utanaðkomandi efna, til dæmis með notkun lampa sem gefa frá sér útfjólublátt ljós eða með notkun sólarorku. Algengt er að fá niðurgang í háfjallaferðum og kviðverkir geta oft fylgt honum. ${ }^{74}$ Í slíkum aðstæðum er mikilvægt að drekka vel af vökva með sykri og söltum. ${ }^{75,76}$ Ekki er mælt með sýklalyfjum nema augljóst sé að um alvarlega bakteríusýkingu sé að ræða og er pá stundum gripið til síprófloxasíns. Sýklalyfjaónæmi er útbreitt og vaxandi vandamál í mörgum peirra landa sem fjallgöngumenn heimsækja. Óparfa sýklalyfjataka raskar jafnframt eðlilegri parmaflóru líkamans sem getur valdið frekari meltingarópægingum eins og niðurgangi. Auk pess eykur sýklalyfjagjöf hættu á að sýklalyfjaónæmar bakteríur nái langvarandi bólfestu í meltingarfærum. ${ }^{77}$ Vindgangur er algengt vandamál og getur bæði tengst breyttu mataræði en einnig pví að hraðari öndun verður til pess að meira er gleypt af lofti. ${ }^{78}$

\section{Augnvandamál}

Helsta augnvandamál í mikilli hæð er bráð hornhimnubólga (acute keratitis), oft kallað snjóblinda, sem stafar af mikilli UV-geislun í hæð ásamt purru og köldu lofti. ${ }^{79}$ Einkenni eru verkir í augum, roði, aðskotahlutstilfinning, aukin táramyndun, ljósfælni og skert sjón. Oft líða nokkrir klukkutímar frá geislun par til einkenni koma fram en oftast ganga pau til baka á einum til premur dögum. Meðferð er fólgin í notkun gervitára og stundum sýklalyfjadropum með bólgueyðandi sterum. ${ }^{79}$ Hægt er að verjast snjóblindu með notkun jöklagleraugna sem verja hornhimnuna gegn UVAog UVB-geislum. ${ }^{79}$

Við súrefnisskort og mikinn kulda getur orðið pynning í sjónhimnu augans og pykknun á hornhimnu, án pess pó að pað valdi óafturkræfum breytingum á sjón. ${ }^{80,81}$ Súrefnisskortur getur einnig valdið augnbotnaskemmdum (high altitude retinopathy), og blæðingum í augnbotninum sem aðeins sjást pegar komið er yfir $4000 \mathrm{~m}$ hæð. ${ }^{82}$ Oft fylgir pessum blæðingum sjónskerðing sem er í flestum tilfellum afturkræf en pessir sjúklingar eru einnig oft með hæðarheilabjúg. ${ }^{82}$

\section{Lokaorð}

Hæðarveiki er algengur sjúkdómur sem stafar af súrefnisskorti og viðbrögðum líkamans við honum. Algengust er háfjallaveiki en lífshættulegur hæðarlungnabjúgur og hæðarheilabjúgur geta einnig komið fyrir. Hægt er að fyrirbyggja hæðarveiki með hæfilegri hæðaraðlögun og lyfjum par sem asetasólamíð er langalgengasta forvarnalyfið. Meðferð allra priggja birtingarforma hæðarveiki felst í tafarlausri lækkun eða súrefnisgjöf sem oft er pó ekki í boði. Er pá gripið til lyfja par sem asetasólamíð, nífedipín, dexametasón og síldenafíl eru mest notuð.

\section{High altitude illness and related diseases - a review}

\section{Tómas Guơbjartsson ${ }^{1,2}$ \\ Engilbert Sigurðsson ${ }^{2,3}$ \\ Magnús Gottfreðsson ${ }^{2,4,5}$ \\ Ólafur Már Björnsson ${ }^{6}$ \\ Gunnar Guð̊mundsson²,7}

Upon reaching a height over $2500 \mathrm{~m}$ above sea level symptoms of altitude illness can develop over $1-5$ days. The risk is mainly determined by the altitude and rate of ascent and the symptoms vary. Most common are symptoms of acute mountain illness (AMS) but more dangerous high altitude cerebral edema (HACE) and high altitude pulmonary edema (HAPE) can also develop. The causes of AMS, HACE and HAPE are lack of oxygen and insufficient acclimatization, but the presenting form is determined by the responses of the body to the lack of oxygen. The most common symptoms of AMS include headache, fatique and nausea, but insomnia and nausea are also common. The most common symptoms of HAPE are breathlessness and lassitude whereas the cardinal sign of HACE is ataxia, but confusion and loss of consciousness can also develop. In this article all three main forms of altitude illness are reviewed. The emphasis is on preventive measures and treatment but new knowledge on pathogenesis is also addressed.

${ }^{1}$ Department of Cardiothoracic Surgery, ${ }^{2}$ Faculty of Medicine, University of Iceland, ${ }^{3}$ Department of Psychiatry, ${ }^{4}$ Department of Sciences, ${ }^{5}$ Department of Infectious Disease, ${ }^{6}$ Sjónlag Eye Clinic, ${ }^{7}$ Department of Respiratory Medicine, Landspitali University Hospital of Iceland.

Key words: High altitude illness, acute mountain sickness, high altitude pulmonary edema, high altitude cerebral edema, pathogenesis, treatment, review.

Correspondence: Tómas Guð̋bjartsson, tomasgudbjartsson@hotmail.com 


\section{Heimildir}

1. Li Y, Zhang Y, Zhang Y. Research advances in pathogenesis and prophylactic measures of acute high altitude illness. Respir Med 2018; 145: 145-52.

2. Davis $C$, Hackett P. Advances in the Prevention and Treatment of High Altitude Illness. Emerg Med Clin North Am 2017; 35: 241-60.

4. Guðmundsson G, Guðbjartsson T. Hæðarveiki - yfirlitsgrein. Læknablaðið 2009; 95: 441-7.

5. Basnyat B, Hofmeyr R, Tolken G, De Decker R. Acute high-altitude illness. S Afr Med J 2017; 107: 1047-8.

7. Luks AM, Auerbach PS, Freer L, Grissom CK, Keyes LE5 McIntosh SE, et al. Wilderness Medical Society Practice Guidelines for the Prevention and Treatment of Acute Altitude Illness: 2019 Update. Wilderness Environ Med 2019; pii: S1080-6032(19)30090-0.

9. Smedley T, Grocott MP. Acute high-altitude illness: clinically orientated review. Br J Pain 2013; 7: 85-94.

10. Villafuerte FC, Corante N. Chronic Mountain Sickness: Clinical Aspects, Etiology, Management, and Treatment. High Alt Med Biol 2016; 17: 61-9.

11. Corante N, Anza-Ramirez C, Figueroa-Mujica R, Macarlupú JL, Vizcardo-Galindo G, Bilo G, et al. Excessive Erythrocytosis and Cardiovascular Risk in Andean Highlanders. High Alt Med Biol 2018; 19: 221-31.

12. Schoene RB. Illnesses at high altitude. Chest 2008; 134: 402 16.

14. Grocott MP, Martin DS, Levett DZ, McMorrow R, Windsor J, Montgomery HE, et al. Arterial blood gases and oxygen content in climbers on Mount Everest. N Engl J Med 2009; 360: 140-9.

16. Bartsch P, Gibbs JS. Effect of altitude on the heart and the lungs. Circulation 2007; 116: 2191-202.

17. Bartsch P, Swenson ER. Acute high-altitude illnesses. N Engl J Med 2013; 369: 1666-7.

18. Hoppeler H, Vogt M, Weibel ER, Fluck M. Response of skeletal muscle mitochondria to hypoxia. Exp Physiol 2003; 88: 109-19.

19. Murray AJ, Horscroft JA. Mitochondrial function at extreme high altitude. J Physiol 2016; 594: 1137-49.

20. Murray AJ, Montgomery HE, Feelisch M, Grocott MPW Martin DS. Metabolic adjustment to high-altitude hypoxia: from genetic signals to physiological implications. Biochem Soc Trans 2018; 46: 599-607.

22. Roach RC, Hackett $\mathrm{PH}$, Oelz $\mathrm{O}$, Bärtsch $\mathrm{P}$, Luks $\mathrm{AM}$ MacInnis MJ, et al. The 2018 Lake Louise Acute Mountain Sickness Score. High Alt Med Biol 2018; 19: 4-6.

23. Honigman B, Theis MK, Koziol-McLain J, Roach R, Yip $\mathrm{R}$, Houston $\mathrm{C}$, et al. Acute mountain sickness in a general tourist population at moderate altitudes. Ann Intern Med 1993; 118: 587-92

25. Montgomery AB, Mills J, Luce JM. Incidence of acute mountain sickness at intermediate altitude. JAMA 1989, 261: 732-4.

26. Bartsch P, Mairbaurl H, Maggiorini M, Swenson ER Physiological aspects of high-altitude pulmonary edema. J Appl Physiol 2005; 98: 1101-10.

28. Luks AM, Swenson ER, Bärtsch P. Acute high-altitude sickness. Eur Respir Rev 2017; 26: pii: 160096.

29. Hultgren HN, Honigman B, Theis K, Nicholas D. Highaltitude pulmonary edema at a ski resort. West J Med 1996 164: 222-7.

30. Bird BA, Wright $\mathrm{AD}$, Wilson $\mathrm{MH}$, Johnson BG, Imray $\mathrm{CH}$ Birmingham Medical Research Expeditionary S. High altitude ataxia--its assessment and relevance. Wilderness Environ Med 2011; 22: 172-6.

31. Bartsch P, Swenson ER. Clinical practice: Acute highaltitude illnesses. N Engl J Med 2013; 368: 2294-302.

32. West JB, American College of P, American Physiological S. The physiologic basis of high-altitude diseases. Ann Intern Med 2004; 141: 789-800.

33. Maggiorini M. High altitude-induced pulmonary oedema. Cardiovasc Res 2006; 72: 41-50
34. Grocott M, Montgomery H, Vercueil A. High-altitude physiology and pathophysiology: implications and relevance for intensive care medicine. Crit Care 2007: 11: 203.

35. Duplain H, Sartori C, Lepori M, Egli M, Allemann Y, Nicod $\mathrm{P}$, et al. Exhaled nitric oxide in high-altitude pulmonary edema: role in the regulation of pulmonary vascular tone and evidence for a role against inflammation. Am J Respir Crit Care Med 2000; 162: 221-4.

36. Sartori C, Vollenweider L, Löffler BM, Delabays A, Nicod $\mathrm{P}, \mathrm{Bärtsch} \mathrm{P}$ et al. Exaggerated endothelin release in highaltitude pulmonary edema. Circulation 1999; 99: 2665-8.

37. Hackett PH, Roach RC. High-altitude illness. N Engl J Med 2001; 345: 107-14

39. Sanchez-Mascunano A, Masuet-Aumatell C, MorchonRamos S, Ramon JM. Relationship of altitude mountain sickness and smoking: a Catalan traveller's cohort study. BMJ Open 2017; 7: e017058.

40. Edwards LM, Murray AJ, Tyler DJ, Kemp GJ, Holloway CJ, Robbins PA, et al. The effect of high-altitude on human skeletal muscle energetics: P-MRS results from the Caudwell Xtreme Everest expedition. PLoS One 2010; 5: e10681.

42. Rupert JL, Koehle MS. Evidence for a genetic basis for altitude-related illness. High Alt Med Biol 2006; 7: 150-167.

44. Puthucheary Z, Skipworth JR, Rawal J, Loosemore M, Van Someren K, Montgomery HE. The ACE gene and human performance: 12 years on. Sports Med 2011; 41: 433-48.

45. Montgomery H, Clarkson P, Barnard M, Bell J, Brynes A, Dollery C, et al. Angiotensin-converting-enzyme gene insertion/deletion polymorphism and response to physical training. Lancet 1999; 353: 541-5.

47. Droma Y, Hanaoka M, Ota M, Katsuyama Y, Koizumi T, Fujimoto $\mathrm{K}$, et al. Positive association of the endothelial nitric oxide synthase gene polymorphisms with high-altitude pulmonary edema. Circulation 2002; 106: 826-30.

48. Gertsch JH, Lipman GS, Holck PS, Merritt A, Mulcahy A, Fisher RS, et al. Prospective, double-blind, randomized, placebo-controlled comparison of acetazolamide versus ibuprofen for prophylaxis against high altitude headache: the Headache Evaluation at Altitude Trial (HEAT). Wilderness Environ Med 2010; 21: 236-43.

49. Kanaan NC, Peterson AL, Pun M, Holck PS, Starling J, Basyal B, et al. Prophylactic Acetaminophen or Ibuprofen Results in Equivalent Acute Mountain Sickness Incidence at High Altitude: A Prospective Randomized Trial. Wilderness Environ Med 2017; 28: 72-8.

51. Nieto Estrada VH, Molano Franco D, Medina RD, Gonzalez Garay AG, Marti-Carvajal AJ, ArevaloRodriguez I. Interventions for preventing high altitude illness: Part 1. Commonly-used classes of drugs. Cochrane Database Syst Rev 2017; 6: CD009761.

52. Ritchie ND, Baggott AV, Andrew Todd WT. Acetazolamide for the prevention of acute mountain sickness--a systematic review and meta-analysis. J Travel Med 2012; 19: 298307

53. McIntosh SE, Hemphill M, McDevitt MC, Gurung TY, Ghale M, Knott JR, et al. Reduced Acetazolamide Dosing in Countering Altitude Illness: A Comparison of 62.5 vs 125 mg (the RADICAL Trial). Wilderness Environ Med 2019; 30: 12-21.

55. O’Hara R, Serres J, Dodson W, Wright B, Ordway J, Powell $\mathrm{E}$, et al. The use of dexamethasone in support of highaltitude ground operations and physical performance: review of the literature. J Spec Oper Med 2014; 14: 53-8.

57. Gonzalez Garay A, Molano Franco D, Nieto Estrada VH, Marti-Carvajal AJ, Arevalo-Rodriguez I. Interventions for preventing high altitude illness: Part 2. Less commonly-used drugs. Cochrane Database Syst Rev 2018; 3 : CD012983.
58. Joyce KE, Lucas SJE, Imray CHE, Balanos GM, Wright AD. Advances in the available non-biological pharmacotherapy prevention and treatment of acute mountain sickness and high altitude cerebral and pulmonary oedema. Expert Opin Pharmacother 2018; 19: 1891-902.

59. Leshem E, Caine Y, Rosenberg E, Maaravi Y, Hermesh $\mathrm{H}$, Schwartz E. Tadalafil and acetazolamide versus acetazolamide for the prevention of severe high-altitude illness. J Travel Med 2012; 19: 308-10.

60. Wang $\mathrm{X}$, Chen H, Li R, Fu W, Yao C. The effects of respiratory inhaled drugs on the prevention of acute mountain sickness. Medicine (Baltimore) 2018: 97: e11788.

61. Deweber K, Scorza K. Return to activity at altitude after high-altitude illness. Sports Health 2010; 2:2 91-300.

63. Meinders AJ, Bosch FH, Meinders AE. [Travelling to high altitudes: do not increase fluid intake]. Ned Tijdschr Geneeskd. 2011; 155: A3526.

64. Simancas-Racines D, Arevalo-Rodriguez I, Osorio D, Franco JV, Xu Y, Hidalgo R. Interventions for treating acute high altitude illness. Cochrane Database Syst Rev 2018; 6: CD009567.

65. Deshwal R, Iqbal M, Basnet S. Nifedipine for the treatment of high altitude pulmonary edema. Wilderness Environ Med 2012; 23: 7-10.

66. Xu Y, Liu Y, Liu J, Qian G. Meta-analysis of clinical efficacy of sildenafil, a phosphodiesterase type- 5 inhibitor on high altitude hypoxia and its complications. High Alt Med Biol 2014; 15: 46-51.

67. Jones BE, Stokes S, McKenzie S, Nilles E, Stoddard GJ. Management of high altitude pulmonary edema in the Himalaya: a review of 56 cases presenting at Pheriche medical aid post (4240 m). Wilderness Environ Med 2013; 24: 32-6.

70. Rodway GW, Edsell ME, Wong B, Windsor JS, Caudwell Xtreme Everest Research G. Improving sleep at altitude: a comparison of therapies. Wilderness Environ Med 2011; 22: 316-20.

71. Mason NP, Barry PW. Altitude-related cough. Pulm Pharmacol Ther 2007; 20: 388-95.

72. Goebbels K, Gieseler U, Schoffl V, Kupper T. Cough and dyspnoea of an asthmatic patient at Mt. Kilimanjaro: a difficult differential diagnosis. Travel Med Infect Dis 2010; 8: 22-8.

73. Thompson AA, Baillie JK, Bates MG, Schnopp MF, Simpson A, Partridge RW, et al. The citric acid cough threshold and the ventilatory response to carbon dioxide on ascent to high altitude. Respir Med 2009; 103: 1182-8.

74. Kuhn C, Apel C, Bertsch D, Grass M, Gschwandtl C, Hundt $\mathrm{N}$, et al. Inpatient treatment of trekkers and Nepalese workers in the high-altitude environment of region 19962011: A retrospective analysis. Travel Med Infect Dis 2018.

76. Sniffen JC, McFarland LV, Evans CT, Goldstein EJC. Choosing an appropriate probiotic product for your patient: An evidence-based practical guide. PLoS One 2018; 13: e0209205.

78. Anand AC, Sashindran VK, Mohan L. Gastrointestinal problems at high altitude. Trop Gastroenterol 2006; 27: 147-53.

79. Izadi $\mathrm{M}$, Jonaidi-Jafari $\mathrm{N}$, Pourazizi $\mathrm{M}$, Alemzadeh-Ansari $\mathrm{MH}$, Hoseinpourfard MJ. Photokeratitis induced by ultraviolet radiation in travelers: A major health problem. J Postgrad Med 2018; 64: 40-46.

80. Bosch MM, Barthelmes D, Merz TM, Knecht PB, Truffer $\mathrm{F}$, Bloch KE, et al. New insights into changes in corneal thickness in healthy mountaineers during a very-highaltitude climb to Mount Muztagh Ata. Arch Ophthalmol 2010; 128: 184-9.

82. Bosch MM, Barthelmes D, Landau K. High altitude retinal hemorrhages--an update. High Alt Med Biol 2012; 13: 240- 